\title{
ВЛАСТИВОСТІ ДОРОЖНІХ БЕТОНІВ ІЗ СУМІШЕЙ РІЗНОЇ PУXOMOCTI
}

\section{PROPERTIES OF ROAD CONCRETE FROM MIXTURES OF VARIOUS MOBILITY}

Толмачов С.М., д.т.н., проф., Бєліченко О.А., к.т.н., ст. наук. співр. (Харківський національний автомобільно-дорожній університет, м. Харків), Толмачов Д.С., к.т.н., головний інженер (ТОВ «Сучасні технології інфраструктури», м. Харків), Даценко В.М., к.т.Н., доц., (Національний транспортний університет, м. Київ), Марченко М.Є., магістрант (Харківський національний автомобільнодорожній університет, м. Харків)

Tolmachov S.M., Doctor of Engineering, Professor, Belichenko O.A., Ph.D. in Engineering, (Kharkov National Automobile und Highway University, Kharkiv), Tolmachov D.S., Ph.D. in Engineering, Chief Engineer (LLC «Modern infrastructure technologies» Kharkiv), Datsenko V.M., Ph.D. in Engineering, associate professor (National Transport University), Marchenko M.E., undergraduate (Kharkov National Automobile und Highway University, Kharkiv)

У статті наведено результати досліджень властивостей бетонів, виготовлених з литих сумішей з осіданням конуса 20 см, сумішей з осіданням конуса 2...4 см, які ущільнюють вібрацією, а також жорстких сумішей, які ущільнюють пресуванням спільно з вібрацією. Визначено витрати цементу, менше яких властивості бетонів, виготовлених із литих сумішей нижче, ніж бетонів 3 більш жорстких сумішей. Показано, що в діапазоні витрат иементу

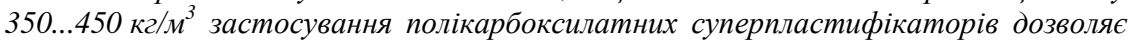
отримувати бетони з високими показниками якості незалежно від їх рухомості. При изьому иемент застосовується максимально ефективно, про щзо свідчить значне зростання коефіцієнта його використання.

The article is devoted to the properties of road concretes, which are made from concrete mixtures of various workability. For the manufacture of road concrete, moderately mobile mixtures and moderately hard mixtures are used. In recent decades, highly mobile and cast concrete mixtures have been used for road surfaces. An analysis of studies that have been carried out by different scientists has shown that there are different opinions on the effect of the mobility of concrete mixtures on the properties of the concrete that is made from them. It is known that an increase in the amount of water in a concrete mix leads to a decrease of the quality of concrete. Therefore, the quality of concretes made from cast mixes is always worse than the quality of concretes made from moderately mobile mixes. Concretes made from hard mixes have the highest characteristics. In practice, concretes made from cast mixes have a strength of more than 
$100 \mathrm{MPa}$. The disadvantages of concretes made from moderately mobile and rigid mixtures with W/C below 0.45 are increased cement consumption, high capillary porosity and low frost resistance. Therefore, the purpose of research is to assess the effect of the mobility of the concrete mixture and, accordingly, the compaction method, on the properties of concrete.

The article presents the results of studies of the properties of concretes made of cast mixes with a slump of $20 \mathrm{~cm}$, mixtures with a slump of $2 \ldots 4 \mathrm{~cm}$, which are compacted by vibration, as well as hard mixes, which are compacted by pressing together with vibration. The consumption of cement is determined, less than which the properties of concretes made from cast mixes are lower than concretes made from harder mixes. It is shown that in the range of cement consumption $350 . . .450 \mathrm{~kg} / \mathrm{m}^{3}$, the use of polycarboxylate superplasticizers makes it possible to obtain concretes with high performance regardless of their mobility. At the same time, cement is used as efficiently as possible, as evidenced by a significant increase in its utilization rate.

Ключові слова: дорожній бетон, рухомість, литі бетонні сумімі, метод ущільнення бетонної суміші, полікарбоксилатний суперпластифікатор.

Keywords: road concrete, mobility, cast concrete mixtures, compaction method the concrete mixture, polycarboxylate superplasticizer.

Актуальність. В технології дорожніх бетонів застосовують суміші які мають різну консистенцію i, відповідно, легкоукладальність. Найбільш часто використовували суміші помірно рухомі і помірно жорсткі. В останні десятиліття для покриттів автомобільних доріг почали застосовувати високорухомі і литі суміші. При цьому для нейтралізації можливих негативних наслідків високої рухомості i водопотреби застосовують безперервне армування бетону за допомогою арматурних каркасів. Властивості бетонної суміші формуються під впливом ряду технологічних факторів: водовмісту суміші, властивостей і витрати в'яжучого, фізикомеханічних і геометричних властивостей заповнювачів, параметрів складу суміші, температури, фактору часу тощо. Усі ці фактори діють одночасно, що значно ускладнює як прогнозування властивостей бетонної суміші, так $\mathrm{i}$ керування ними. У литих i високорухомих сумішах вплив більшості зазначених чинників значно знижено через те, що крупні заповнювачі якби плавають в розчинній суміші, а дрібні - в цементному тісті. При цьому в'язкість дисперсних середовищ досить низька, що зумовлено дією суперпластифікаторів, які обов'язково застосовують в дорожніх бетонах. 3 іншого боку, висока рухомість і низька в'язкість таких систем сприяє якісному ущільненню (наприклад, SCC - самоущільнюющієся суміші) i спрощує можливість впливу на властивості одержуваних бетонів. Існують різні погляди на ефективність застосування різних способів ущільнення для отримання бетонів 3 високими експлуатаційними властивостями. Тому актуальним $є$ дослідження фізико-механічних властивостей бетонів із сумішей різної рухомості, ущільнених різними способами. 
Стан питання. Легкоукладальність - технологічна властивість бетонних сумішей різної консистенції (жорсткої, густої, рідкої), яка характеризує здатність суміші заповнювати форму (або опалубку) та ущільнюватися під час бетонування виробів і конструкції за рахунок зовнішніх дій, або за власною масою [1]. У цьому визначенні основна увага приділена консистенції, і як наслідок, здатності сумішей ущільнюватися, що відображає технологічну властивість сумішей. В [2] наведено дещо інше визначення легкоукладальності: «Легкоукладальність бетонних сумішей - властивість бетонних сумішей різної консистенції заповнювати форму i ущільнюватися до заданої щільності». У цьому визначенні основною вважається фізична властивість бетонної суміші - щільність. При цьому консистенція суміші не враховується, а, значить, не враховується і спосіб ущільнення.

Основним фактором, який впливає на властивості бетонної суміші і бетону є водовміст. Вода утримується в порах і капілярах бетонної суміші i чинить на систему структуруючу дію завдяки значно великій поверхні контакту з частинками різної крупності. На систему впливають внутрішні напруження стиску, зумовлені капілярними явищами, силами молекулярної взаємодії тощо, що забезпечує зв'язність системи, збереження в певних умовах форми і здатності до деформацій.

Поряд із фізико-хімічно і фізично зв'язною водою у структурі бетонної суміші у прошарках між частинками твердої фази є вільна вода, Яка безпосередньо впливає на реологічні властивості системи в цілому. Чим товстіші ці заповнені водою прошарки, тим менший граничний опір зсуву і в'язкість, тим рухливіша бетонна суміш. Однак підвищувати рухомість суміші збільшенням вмісту вільної води можна тільки до певної межі - так званої водоутримувальної здатності бетонної суміші. Вище цієї межі, яка залежить від складу суміші і властивостей iі компонентів, спостерігаються вже деструктивні явища - зменшуються сили капілярної взаємодії, суміш починає розшаровуватися, стає неоднорідною. Частина води вже не утримується у структурі і під впливом сили тяжіння витікає із суміші (гравітаційна вода).

Витрата в'яжучого в певних межах при постійних водовмісті та інших параметрах складу незначно впливає на легкоукладальність бетонної суміші. Це зумовлено тим, що при зміні витрати цементу, з одного боку, змінюються реологічні властивості цементного тіста як основного носія властивостей бетонної суміші, а 3 другого - змінюється кількість цементного тіста. Ці зміни чинять протилежний вплив на властивості суміші, нейтралізуючи одна одну. Дослідження показують, що витрата цементу може розглядатися як фактор легкоукладальності бетонної суміші тільки при низьких (менше ніж $200 \mathrm{\kappa} / \mathrm{M}^{3}$ ) і високих (більше ніж $400 \mathrm{\kappa r} / \mathrm{m}^{3}$ ) його значеннях $[3,4]$. 
В останні кілька десятиліть широке поширення в світі отримали високорухомі i литі суміші, які застосовують для промислового i цивільного житлового будівництва. Склад таких сумішей досить складний і налічує від 8 до 12 компонентів. У дорожньому будівництві такі суміші не застосовують в першу чергу через високу вартість і дефіцит компонентів. С досить велика кількість робіт, в яких для поліпшення зв'язності, зниження розшарування суміші рекомендується застосовувати органо-мінеральні добавки, що складаються 3 суперпластифікатора i дисперсної мінеральної добавки [5 - 7]. Однак, застосування таких добавок в технології дорожніх бетонів на даному етапі досить складно через високу вартість мінеральних добавок i ïх дефіцит. Крім того, застосування дисперсних добавок призводить до необхідності збільшення часу перемішування бетонних сумішей, що практично неможливо при високій швидкості укладання бетону в покриття.

В той же час отримання високоміцних бетонів, класів не нижче В40 із високорухомих бетонних сумішей марки за легкоукладальністю S4 можна забезпечити за рахунок застосування різних хімічних добавок: пластифікаторів, прискорювачів твердіння, стабілізаторів [8]. Цей шлях видається найпростішим i найменш витратним. Сучасні суперпластифікатори на полікарбоксилатній основі володіють комплексом властивостей, які дозволяють забезпечити високу якість дорожніх бетонів.

Це підтверджують дослідження Р.Ф. Рунової зі співробітниками, в яких показано, що морозостійкість литих сумішей марки $\mathrm{S} 43$ полкарбоксілатним суперпластифікатором Sika Plast 2508HE відповідає марці F200 [9], що відповідає вимогам ДСТУ 8858 [10].

3 іншого боку у дослідженнях, проведених під керівництвом Л.Й. Дворкіна зазначено, що в бетонах з В/Ц нижче 0,45, що забезпечено за рахунок застосування полікарбоксилатів, може спостерігатися перевитрата цементу, зростання капілярної пористості і зниження морозостійкості [11].

Тому метою цієї статті $є$ оцінка впливу рухомості бетонної суміші і методу ущільнення бетону на його властивості.

Матеріали і методи дослідження. У дослідженнях застосовували цемент ПЦ І-500 Р-Н виробництва «ЮГцемент» філії ПРАТ «Дікергофф Цемент Україна», пісок кварцовий 3 модулем крупності 1,86 , щебінь гранітний фр. 5-10 мм та 10-20 мм. Використовували стандартні методи випробування зразків бетонів на міцність при стиску, водопоглинання, морозостійкість і стираність у відповідності 3 чинними нормативними документами.

Експериментальні дослідження. Дослідження проводили на бетонних сумішах різної рухомості, які ущільнювали литтєвим способом, вібрацією і вібропресуванням. Легкоукладальність цих сумішей була: рухомість ОК $=18 \ldots 22 \mathrm{~cm}$, ОК $=2 \ldots 4$ см і Ж $=10 \ldots 15$ с, відповідно. У 
складах сумішей змінювали витрати цементу, а також в деяких складах використовували полікарбоксилатний суперпластифікатор (СП) Sika Plast $2508 \mathrm{HE}$ у кількості 0,6 \% від маси цементу. Отримані раніше дані свідчать про низьку ефективність застосування суперпластифікаторів в пресованих бетонах, тому в склади вібропресованих бетонів їх не вводили $[12,13]$. Отримані результати було зведено у табл.

Таблиця 1

Властивості бетонів із сумішей різної легкоукладальності

\begin{tabular}{|c|c|c|c|c|c|c|}
\hline \multirow[b]{2}{*}{$\begin{array}{l}\text { Спосіб } \\
\text { ущіль- } \\
\text { нення }\end{array}$} & \multirow[b]{2}{*}{ 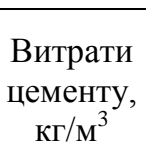 } & \multirow[b]{2}{*}{ Добавки } & \multicolumn{4}{|c|}{ Показники якості } \\
\hline & & & $\begin{array}{l}\mathrm{R}_{\mathrm{cr}} \\
\mathrm{MПа}\end{array}$ & $\mathrm{W}, \%$ & $\begin{array}{l}\text { Марка за } \\
\text { морозості } \\
\text { йкістю, F }\end{array}$ & $\begin{array}{c}\text { Стира- } \\
\text { ність, G, } \\
\text { г/см } \\
\end{array}$ \\
\hline \multirow{6}{*}{ 焉 } & 250 & - & $10 \ldots 12$ & $8 \ldots 10$ & 50 & $1,2 \ldots 1,5$ \\
\hline & 250 & $\mathrm{C \Pi}$ & $20 \ldots .25$ & $5 \ldots 6$ & $100 \ldots 150$ & $0,6 \ldots 0,7$ \\
\hline & 350 & - & $20 \ldots 22$ & $6 \ldots 7$ & $50 \ldots 100$ & $0,5 \ldots 0,8$ \\
\hline & 350 & $\mathrm{C \Pi}$ & $35 \ldots 40$ & $3 \ldots 4$ & $150 \ldots 200$ & $0,3 \ldots 0,4$ \\
\hline & 450 & - & $30 \ldots 35$ & $3 \ldots 4$ & 150 & $0,4 \ldots 0,5$ \\
\hline & 450 & СП & $45 \ldots .55$ & $1,5 \ldots 2$ & $\begin{array}{c}\text { більше } \\
200\end{array}$ & $0,15 \ldots 0,2$ \\
\hline \multirow{6}{*}{ : } & 250 & - & $15 \ldots 20$ & $6 \ldots 6,5$ & $75 \ldots 100$ & $0,5 \ldots 0,6$ \\
\hline & 250 & $\mathrm{C \Pi}$ & $20 \ldots 25$ & $5 \ldots 6$ & $100 \ldots 150$ & $0,4 \ldots 0,5$ \\
\hline & 350 & - & $25 \ldots 30$ & $4 \ldots 5$ & $100 \ldots 150$ & $0,35 \ldots 0,4$ \\
\hline & 350 & $\mathrm{C \Pi}$ & $35 \ldots 40$ & $2 \ldots 3$ & $200 \ldots 250$ & $0,2 \ldots 0,3$ \\
\hline & 450 & - & $40 \ldots 45$ & $2 \ldots 3$ & $150 \ldots 200$ & $0,25 \ldots 0,3$ \\
\hline & 450 & СП & $50 \ldots 60$ & $1 \ldots 1,5$ & $\begin{array}{c}\text { більше } \\
300 \\
\end{array}$ & $0,15 \ldots 0,2$ \\
\hline \multirow{5}{*}{ 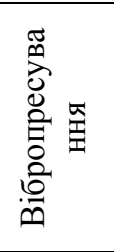 } & 50 & - & $3 \ldots 5$ & $10 \ldots 12$ & - & - \\
\hline & 150 & - & $5 \ldots 10$ & $8 \ldots 10$ & $50 \ldots 75$ & $0,8 \ldots 1,0$ \\
\hline & 250 & - & $15 \ldots 20$ & $5 \ldots 6$ & $100 \ldots 150$ & $0,4 \ldots 0,5$ \\
\hline & 350 & - & $30 \ldots 40$ & $4 \ldots 5$ & $200 \ldots 250$ & $0,2 \ldots 0,3$ \\
\hline & 450 & - & $40 \ldots .50$ & $3 \ldots 4$ & $\begin{array}{c}\text { більше } \\
300\end{array}$ & $0,15 \ldots 0,2$ \\
\hline
\end{tabular}

Бетони, виготовлені з литих сумішей, без СП, з витратою цементу 250 кг $/ \mathrm{m}^{3}$, мають низьку міцність, високе водопоглинання і стираність, які перевищують вимоги ДСТУ 8858. Їх морозостійкість не відповідає навіть вимогам, що пред'являються до нижніх шарів покриттів. Коефіцієнт ефективності використання цементу в них обмежений $\mathrm{K}_{\text {цे }}^{\text {ц }}=0,04 \ldots 0,048$ МПа/кг цементу, що дуже мало. Бетони, отримані віброущільненням, при таких же витратах цементу мають в $1,5 \ldots 2$ рази більшу міцність і значно 
менші водопоглинання і стираність. Морозостійкість цих бетонів в два рази вище. Коефіцієнт використання цементу в них становить $\mathrm{K}_{\text {це }}^{\text {еф }}=$ 0,06...0,08 МПа/кг, що свідчить про значно більшу ефективність використання в'яжучого в менш рухомих бетонних сумішах. Морозостійкість таких бетонів відповідає марці F100. Цікаво, що для сумішей, ущільнених вібропресуванням, показники якості, при таких же витратах цементу, приблизно однакові у порівнянні 3 віброущільненими бетонами. Однак, введення до складу литих бетонів СП полікарбоксилатного типу істотно змінює властивості бетонів. Міцність таких бетонів зростає в 2 рази, а морозостійкість - у 2...3 рази в порівнянні 3 бетонами без СП і досягає аналогічних показників віброущільнених бетонів. Стираність литих бетонів вище на $40 \ldots 50 \%$, ніж у віброущільнених, що можна пояснити надлишком вільної води в них, під впливом якої формується більш пориста структура поверхневого шару.

Збільшення в литих сумішах витрати цементу до 350 кг/м ${ }^{3}$ покращує властивості бетону: міцність зростає в $1,8 \ldots 2$ рази, водопоглинання знижується на $25 \ldots 30 \%$, стираність - в $2 \ldots 2,5$ рази, а морозостійкість

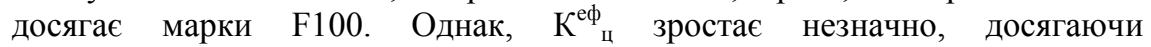
$0,057 \ldots 0,063 \mathrm{MПа} / к г$. У той же час, збільшення витрати цементу до $350 \mathrm{\kappa} / \mathrm{M}^{3}$ в віброущільнених бетонах, дозволяє підвищити їх міцність на $20 . .25 \%$, знизити водопоглинання на $30 . .50 \%$, а стираність - на $15 . .20 \%$ у порівнянні з бетонами 3 витратою цементу $250 \mathrm{\kappa г} / \mathrm{M}^{3}$. Морозостійкість

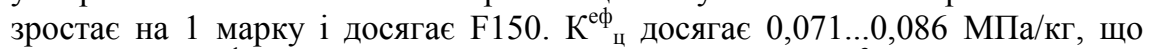

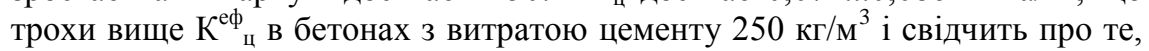
що при збільшенні витрати цементу в цьому діапазоні ефективність його застосування в віброущільнених бетонах знижується.

У вібропресованих бетонах таке збільшення витрати цементу принципово змінюе властивості бетонів. Міцність зростає в 2 рази, стираність знижується в $1,7 \ldots 2$ рази, морозостійкість зростає на 2 марки. При цьому водопоглинання знижується незначно - на $20 \%$. ${ }_{\text {ц }}^{\mathrm{eф}}$ становить 0,086...0,11 МПа/кг, що значно вище, ніж у вібропресованих бетонах 3 витратою цементу $250 \mathrm{\kappa} / \mathrm{M}^{3}$ і свідчить про високу ефективність використання цементу.

Введення до складу литих бетонів 3 витратою цементу 350 кг $/ \mathrm{m}^{3} \mathrm{CП}$, дозволяє підвищити їх міцність на $75 \ldots 80 \%$, знизити водопоглинання i стираність в $1,8 \ldots 2$ рази і збільшити морозостійкість на дві марки. $K_{\text {ер }}^{\text {еф }}$ досягає значень $0,1 \ldots 0,11 \mathrm{MПа/кг,} \mathrm{що} \mathrm{дорівнює} \mathrm{показникам} \mathrm{для}$ віброущільнених і вібропресованих бетонів. Це свідчить про те, що ефективність використання цементу в литих бетонах зростає стрибкоподібно при введенні в їх склад СП. Подальше збільшення витрати

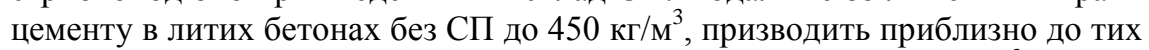
же результатів, що і в литих бетонах з витратою цементу $350 \mathrm{\kappa r} / \mathrm{m}^{3}$, але які містять СП. При цьому міцність навіть зменшується. Це підтверджує $\mathrm{K}_{\text {е }}^{\text {, }}$ 
який значно знижується до рівня $0,7 \ldots 0,8 \mathrm{MПа/кг.} \mathrm{Це} \mathrm{свідчить} \mathrm{про} \mathrm{те,} \mathrm{що}$ збільшення витрати цементу в литих сумішах понад $350 \mathrm{\kappa г} / \mathrm{m}^{3}$ може бути неефективним і вимагає обгрунтування. Для віброущільненних бетонів таке збільшення вмісту цементу призводить до незначного збільшення міцності - на $12 \ldots 15 \%$, можливого зниження морозостійкості на одну марку i постійності стираності i водопоглинання. При цьому $\mathrm{K}_{\text {ц }}^{\mathrm{ed}}$ становить $0,08 \ldots 0,1 \mathrm{MПа/кг.} \mathrm{В} \mathrm{цілому} \mathrm{можна} \mathrm{сказати,} \mathrm{що} \mathrm{збільшення} \mathrm{кількості}$

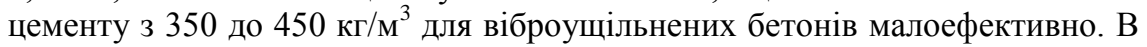
цьому випадку краще застосовувати СП.

Аналогічні результати за міцністю отримані для вібропресованих бетонів. Однак, таке збільшення витрати цементу призвело до зростання морозостійкості на одну марку, зниження водопоглинання на $25 . .35 \%$. і стираності на $35 \ldots 50 \%$, в порівнянні 3 бетонами 3 витратою цементу 350 кг $/ \mathrm{M}^{3}$. $\mathrm{K}_{\text {ц }}^{\text {ц }}$ не змінюється, що свідчить про те, що поліпшення властивостей вібропресованих бетонів за рахунок підвищення витрати цементу від 350 до 450 кг/м ${ }^{3} \epsilon$ малоефективним. Введення до складу литих бетонів 3 витратою цементу $450 \mathrm{\kappa} / \mathrm{m}^{3} \mathrm{CП}$, дозволяє істотно підвищити їх міцність (на $50 \ldots 60 \%$ ), морозостійкість (на одну марку), в 2...2,5 рази знизити водопоглинання і стираність в порівнянні з бетонами без СП. К ${ }_{\text {ц }}^{\mathrm{e \phi}}$ для таких бетонів досягає $0,1 \ldots 0,122 \mathrm{MПа} / к г$, що перевищує цю характеристику для пресованих бетонів. Властивості віброущільнених бетонів, що містять СП, при витраті цементу 450 кг $/ \mathrm{m}^{3}$ також поліпшуються. У порівнянні з бетонами без СП міцність зростає на 25...35 $\%$, морозостійкість - на одну марку (може бути і вище), водопоглинання знижується в 2 рази, а стираність - на $50 \ldots 70 \%$. Але при цьому $\mathrm{K}_{\text {ц }}^{\text {ц }}$ зростає i досягає максимальних значень $0,111 \ldots 0,133 \mathrm{MПа/кг.} \mathrm{Це} \mathrm{підтверджує}$ високу ефективність застосування СП у віброущільнених бетонах при витратах цементу $350 \ldots 450 \mathrm{\kappa} / \mathrm{M}^{3}$.

Висновки. 1. Встановлено, що застосування литих бетонних сумішей 3 витратами цементу $250 \mathrm{\kappa r} / \mathrm{m}^{3}$ i менше не дозволяє отримати бетони 3 високими фізико-механічними властивостями. Для поліпшення цих властивостей до складу таких сумішей необхідне введення суперпластифікаторів.

2. Показано, що застосування суперпластифікаторів полікарбоксилатного типу особливо ефективно для литих i віброущільнених бетонів при витратах цементу $350 \ldots 450$ кг/м ${ }^{3}$.

3. Встановлено, що збільшення витрати цементу в вібропресованих бетонах до $350 \mathrm{\kappa г} / \mathrm{M}^{3}$ призводить до значного поліпшення всіх показників якості. Однак, подальше збільшення витрати цементу до $350 \mathrm{\kappa г} / \mathrm{m}^{3}$ не настільки значно впливає на властивості таких бетонів. 


\section{References}

1. Gocz V.I. Betony i budivel’ni rozchyn`. Ky`yiv: TOV UVPK «Eks ob», Ky`yiv: KNUBA, 2003. $472 \mathrm{~s}$.

2. DSTU B A.1.1-59-95 Texnologiya vazhkyx betoniv ta zalizobetonnyx vyrobiv. Betonni, rozchynni sumishi ta betony. Terminy ta vyznachennya. [Chynnyj vid 1995-0701]. Vyd. oficz. Kyyiv: Derzhkommistobuduvannya Ukrayiny, 1995. 29 s.

3. Radovskij B.S. Stroitelstvo dorog s cementobetonnymi pokrytiyami v SShA: novye tendencii (Organizaciya i napravleniya issledovanij $\mathrm{v}$ oblasti cementobetonnyh pokrytij). Dorozhnaya tehnika. 2010. № 10. S. 62-70.

4. Batrakov V.G. Modificirovannye betony. Teoriya i praktika. Moskva: izd-vo «Tehnoproekt». 1998. $768 \mathrm{~s}$.

5. Batudaeva A.V., Kardumyan G.S., Kaprielov S.S. vysokoprochnye modificirovannye betony iz samovyravnivayushihsya smesej. Beton i zhelezobeton. 2005. № 4. S. 14-18.

6. Zajchenko N.M., Sahoshko E.V. Samouplotnyayushiesya betonnye smesi s kombinirovannymi organo-mineralnymi modifikatorami. Budivelni konstrukciyi: Mizhvidomchij naukovo-tehnichnij zbirnik naukovih prac (budivnictvo). Kiyiv, DP NDIBK, 2009. Vip. 72. S. 580-588.

7. Artelt C., Garcia E. Impact of superplasticizer concentration and ultra-fine particles on the rheological behaviour of dense mortar suspensions. Cement and Concrete Research. 2008. Vol. 38, No. 5. P. 633-642.

8. Mushtakov M.I., Korolev A.S., Butakova M.D., Zyryanov F.A. Bystrotverdeyushie betony dlya monolitnogo stroitelstva. Sbornik trudov Vserossijskoj nauchno-prakticheskoj konferencii «Stroitelnoe materialovedenie - teoriya i praktika». M.: izd-vo SIP RIA. 2006. S. 183-185.

9. Runova R.F., Rudenko I.I., Troyan V.V. Formirovanie svojstv betona v monolitnoj konstrukcii. Visnik ODABA. Odessa, 2013. Vip. 52. S. 224-229.

10. DSTU 8858:2019 Sumishi cementobetonni dorozhni ta cementobeton dorozhnij. Texnichni umovy. [Chynnyj vid 2020-07-01]. Vyd. oficz. Ky`yiv: DP «UkrNDNCz», 2020. $20 \mathrm{~s}$.

11. V'yazhuchy materialy, betony i rozchyny u suchasnomu budivnycztvi / L.J. Dvorkin ta in.; Rivne: NUVGP, 2012. 268 s.

12. Tolmachev S.N., Kostenko Yu.A., Marakina L.D. Mehanizm strukturoobrazovaniya v cementnom kamne uplotnennom razlichnymi sposobami. Visnik NTI “HPI” № 23. T.1: «Himiya, himichni tehnologiyi ta ekologiya». Harkiv: NTU “HPI”. 2001. S. 30-33.

13. Tolmachev S.N., Belichenko E.A., Tolmachev D.S. Pressovannye cementnye betony dlya stroitelstva avtomobilnyh dorog. "Avtomobilnye dorogi: bezopasnost i nadezhnost»: sb. dokladov Mezhdunar. yubilejnoj nauchno-tehnich. konf., Minsk, 2018. S. 201-209.

\section{Список використаної літератури}

1. Гоц В.І. Бетони і будівельні розчини. Київ: ТОВ УВПК «Екс об», Київ: КНУБА, 2003. 472 с.

2. ДСТУ Б А.1.1-59-95 Технологія важких бетонів та залізобетонних виробів. Бетонні, розчинні суміші та бетони. Терміни та визначення. [Чинний від 1995-0701]. Вид. офіц. Київ: Держкоммістобудування України, 1995. 29 с. 
3. Радовский Б.С. Строительство дорог с цементобетонными покрытиями в США: новые тенденции (Организация и направления исследований в области цементобетонных покрытий). Дорожная техника. 2010. № 10. С. 62-70.

4. Батраков В.Г. Модифицированные бетоны. Теория и практика. Москва: изд-во «Технопроект». 1998. 768 с.

5. Батудаева А.В., Кардумян Г.С., Каприелов С.С. высокопрочные модифицированные бетоны из самовыравнивающихся смесей. Бетон $u$ железобетон. 2005. № 4. С. 14-18.

6. Зайченко Н.М., Сахошко Е.В. Самоуплотняющиеся бетонные смеси с комбинированными органо-минеральными модифікаторами. Будівельні конструкиї: Міжвідомчий наук.-техн. зб. наук. прац̧ь (будівництвво). Київ, ДП НДІБК, 2009. Вип. 72. С. 580-588.

7. Artelt C., Garcia E. Impact of superplasticizer concentration and ultra-fine particles on the rheological behaviour of dense mortar suspensions. Cement and Concrete Research. 2008. Vol. 38, No. 5. P. 633-642.

8. Муштаков М.И., Королев А.С., Бутакова М.Д., Зырянов Ф.А. Быстротвердеющие бетоны для монолитного строительства. Сборник трудов Всероссийской научно-практической конференции "Строительное материаловедение - теория и практика». М.: изд-во СИП РИА. 2006. С. 183-185.

9. Рунова Р.Ф., Руденко И.И., Троян В.В. Формирование свойств бетона в монолитной конструкции. Вісник ОДАБА. Одесса, 2013. Вип. 52. С. 224-229.

10. ДСТУ 8858:2019 Суміші цементобетонні дорожні та цементобетон дорожній. Технічні умови. [Чинний від 2020-07-01]. Вид. офіц. Київ: ДП «УкрНДНЦ», 2020.20 с.

11. В'яжучи матеріали, бетони і розчини у сучасному будівництві / Л.Й. Дворкін та ін.; Рівне: НУВГП, 2012. 268 с.

12. Толмачев С.Н., Костенко Ю.А., Маракина Л.Д. Механизм структурообразования в цементном камне уплотненном различными способами. Вісник НТІ “ХПІ” № 23. Т.1: «Хімія, хімічні технології та екологія». Харків: НТУ "ХПІ". 2001. С. 30-33.

13. Толмачев С.Н., Беличенко Е.А., Толмачев Д.С. Прессованные цементные бетоны для строительства автомобильных дорог. «Автомобильные дороги: безопасность и надежность»: сб. докладов Междунар. юбилейной научно-технич. конф., Минск, 2018. - С. 201-209. 